\title{
A Holistic Review on Euro-Asian Lactic Acid Bacteria Fermented Cereals and Vegetables
}

\author{
Tolulope Joshua Ashaolu ${ }^{1,2}$ and Anna Reale ${ }^{3, *}$ (D) \\ 1 Smart Agriculture Research and Application Team, Ton Duc Thang University, Ho Chi Minh City 758307, \\ Vietnam; tolulopeashaolu@tdtu.edu.vn \\ 2 Faculty of Applied Sciences, Ton Duc Thang University, Ho Chi Minh City 758307, Vietnam \\ 3 Institute of Food Science, National Research Council, ISA-CNR, 83100 Avellino, Italy \\ * Correspondence: anna.reale@isa.cnr.it; Tel.: +39-0825-299541
}

Received: 1 July 2020; Accepted: 31 July 2020; Published: 3 August 2020

\begin{abstract}
Lactic acid fermentation is one of the oldest methods used worldwide to preserve cereals and vegetables. Europe and Asia have long and huge traditions in the manufacturing of lactic acid bacteria (LAB)-fermented foods. They have different cultures, religions and ethnicities with the available resources that strongly influence their food habits. Many differences and similarities exist with respect to raw substrates, products and microbes involved in the manufacture of fermented products. Many of them are produced on industrial scale with starter cultures, while others rely on spontaneous fermentation, produced homemade or in traditional events. In Europe, common LAB-fermented products made from cereals include traditional breads, leavened sweet doughs, and low and non-alcoholic cereal-based beverages, whereas among vegetable ones prevail sauerkraut, cucumber pickles and olives. In Asia, the prevailing LAB-fermented cereals include acid-leavened steamed breads or pancakes from rice and wheat, whereas LAB-fermented vegetables are more multifarious, such as kimchi, sinki, khalpi, dakguadong, jiang-gua, soidon and sauerkraut. Here, an overview of the main Euro-Asiatic LAB-fermented cereals and vegetables was proposed, underlining the relevance of fermentation as a tool for improving cereals and vegetables, and highlighting some differences and similarities among the Euro-Asiatic products. The study culminated in "omics"-based and future-oriented studies of the fermented products.
\end{abstract}

Keywords: lactic acid bacteria; fermented foods; cereals; vegetables; Europe; Asia; beverages; starter cultures; rice; wheat

\section{Introduction}

Globally, the choice and consumption of healthier and safe food products has steadily increased in the past few decades, emphasizing the diet-human health connectivity. In this sense, functional products are excellent food options, as they aim to improve life quality by preventing nutrition-related diseases [1]. A huge percentage of these functional products are usually produced by lactic acid bacteria (LAB) via fermentation.

Fermentation is a cheap food biotechnological process used worldwide, a tool that is helpful in the production of several functional foods and beverages. The pyramidal base for the production of traditional fermented foods is in the household, in which an enormous amount of microbial and raw matter inoculants are used in a haphazard manner [2]. The low cost of fermentation and LAB cultures have made it easier to ferment numerous substrates from vegetables, cereals, dairy-milk, fruits and starchy root crops in order to improve their nutritional status, reduce toxic and anti-nutritional elements, and improve the shelf life and sensory properties of foods [3]. Whether in a solid state or submerged state, fermentation, through acidification, alcoholization, proteolysis and amino acid 
conversions, leads to the production of health-promoting food products with desirable qualities like shelf-life, texture, taste, mouthfeel, flavor and color [4].

Europe and Asia have long and huge traditions in the manufacturing of several LAB-fermented foods and, in the last years, thanks to scientific progress and "omic" studies, the knowledge, safety and regulation of many fermented products have increased.

Trade between European and Asian countries accounts for about half of the global trade, and though intra-regional trade is four times higher than cross-regional trade, the Euro-Asian regions trade more between them than between any other regions of the world [5]. As significant as the Euro-Asian economic ties are to the world, their foods are of equal global importance. The use of wheat and olive oil prevails in European foods with sweet or salt tastes, but Asian foods often include rice, sesame oil and soy sauce with spicy, bitter or sour tastes.

In general, natural fermentations are performed by lactic acid bacteria and yeasts. These microorganisms often act in synergy. Yeasts play an important role in the production of numerous fermented beverages and leavened breads thanks to their ability to produce high levels of ethanol, carbon dioxide and highly desirable aromatic compounds, while lactic acid bacteria are particularly important in the fermentation of cereals, vegetables, meat and dairy products for their acidifying and proteolytic activity, and for their ability to produce aromatic compounds.

In this review, our interest has focused only on the study of lactic acid fermentation, which, although having a secondary role for some fermented products, is however decisive in defining the final quality of the products.

This review considers cereals and vegetable products obtained via lactic acid bacteria fermentation in Europe and Asia. The review includes the relevance of fermentation as a tool for improving cereals and vegetables, the concept of lactic acid bacteria fermentation and the Euro-Asian LAB-fermented cereals and vegetables list, highlighting differences and similarities among products. It further describes an outlook on prospective studies and considerations.

\section{Fermentation as a Tool for Improving Cereals and Vegetables}

Cereals are the main consumed staple-food in most parts of the world. Their derived products can also be consumed alongside popular vegetables to make exotic delicacies. Being rich sources of carbohydrates and mineral nutrients, cereals and vegetables proffer numerous sensory, nutritional and physiological potentials when fermented. Natural or spontaneous fermentation was used by our ancestors for the preparation and preservation of foods like cereals and vegetables, without having any knowledge of microbes involved in the process [6].

In Europe, Asia or in other parts of world, people still practice the old traditional method of preparation of breads or loaves without using any commercial strains of baker's yeast [7]. Furthermore, perishable and seasonal leafy vegetables, radish, onions, cucumbers and young edible bamboo tender shoots are traditionally fermented into traditional edible products such as khalpi, cucumbers, oiji, hom-dong, sauerkraut, olives, and jiang-gua [8]. Over time, pickling various types of vegetables by fermentation has become common in order to elicit some distinctive tastes from the products.

A general classification of food fermentation includes different categories: (a) fermentations, producing textured vegetable protein as meat substitutes in legume/cereal mixtures; (b) high salt/savory meat flavored/amino acid/peptide sauce and paste fermentations; (c) lactic acid, alcoholic, acetic acid/vinegar, alkaline fermentations; (d) leavened breads/sour dough breads; (e) flat unleavened breads [9].

LAB fermentation enables the preservation of numerous cereals and vegetables, as well as the transformation of the raw material into a new product with unique sensorial properties, new flavors, aromas, better textures and enhanced nutritional value. During fermentation, raw substrates become colonized by autochthonous microorganisms that use their enzymes to digest the food components into acceptable final products to the prospective consumers $[10,11]$. 
Cereals, for example, lack the essential amino acids and some other vital compounds for proper nutrition, thus fermentation helps in releasing these compounds by decreasing the levels of carbohydrates and non-digestible polysaccharides and oligosaccharides in cereals, and increasing the essential amino acids' production and bioavailability $[12,13]$. Polyphenols, phytates and tannins are non-nutrients decreased in the process of LAB fermentation $[14,15]$, while the binding capacity, digestibility, absorption and solubility of minerals such as iron increase [16].

The use of a desirable starting culture for the making of fermented foods may prevent contamination, and helps retain consistent food quality [6]. Therefore, important criteria to be considered when selecting fermentative microbial species and strains for the production of functional foods and beverages include the safety of microbial species/strains, nutritional quality, protectiveness, broad fermentability, bioactivity and sensory qualities $[2,17]$.

\section{Lactic Acid Bacteria (LAB) Fermentation}

Fermentation is a way to exploit the activities of microorganisms so as to preserve and transform raw materials into high-quality products. Lactic acid fermentation is the oldest and most popular way to improve the functionality, nutritional value, taste, appearance, shelf-life and safety of cereal foods, and reduce the energy required for cooking [18].

Examples of lactic acid-fermented products, i.e., products primarily fermented by lactic acid bacteria, include yoghurt, cheese, sourdough, olives in the western world, sauerkraut (fermented cabbage from eastern and central Europe), thai pickled vegetables (fermented cabbage from Thailand), sausages, Chinese steamed bun, kimchi (fermented and spiced Napa cabbage from Korea), fermented soybean and rice [19].

Responsible for this kind of fermentation are the lactic acid bacteria, non-spore forming, acid-tolerant bacteria classified as anaerobic, facultative anaerobic bacteria, aerobic or microaerophilic, catalase-negative, and Gram-positive with coccoid or rod-shaped cells, which may form chains, pairs or tetrads [18].

The new bacterial taxonomy classifies the lactic acid bacteria in the phylum Firmicutes, class Bacilli, order Lactobacillales, and refers to five families: Lactobacillaceae (which now includes the family Leuconostocaceae), Streptococcaceae, Enterococcaceae, Carnobacteriaceae and Aerococcaceae [20].

Lactic acid bacteria are among the most familiar bacterial groups to humans, since they are widespread in nature, occurring in numerous nutrient-rich habitats such as plant, soil, animals and humans. They can as well be found fermenting already consumed food products in the gut [21]. The isolation and identification of lactic acid bacteria from raw matrices (grains, crops) is naturally fermented foods (dairy products, cereals, fruits and vegetables) is well documented [8].

Many genera/species of microorganisms have been reported in relation to various fermented foods and beverages across the world.

The lactic acid bacteria associated with foods include species of the genera Lactobacillus (old classification), Leuconostoc, Pediococcus, Lactococcus, and Streptococcus, as well as the more peripheral Aerococcus, Carnobacterium, Enterococcus, Oenococcus, Sporolactobacillus, Tetragenococcus, Vagococcus, and Weissella.

Actually, scientists have recently reclassified the genus Lactobacillus into 25 genera, including the emended genus Lactobacillus, which includes host-adapted organisms that have been referred to as the L. delbrueckii group, Paralactobacillus and 23 novel genera: Acetilactobacillus, Agrilactobacillus, Amylolactobacillus, Apilactobacillus, Bombilactobacillus, Companilactobacillus, Dellaglioa, Fructilactobacillus, Furfurilactobacillus, Holzapfelia, Lacticaseibacillus, Lactiplantibacillus, Lapidilactobacillus, Latilactobacillus, Lentilactobacillus, Levilactobacillus, Ligilactobacillus, Limosilactobacillus, Liquorilactobacillus, Loigolactobacilus, Paucilactobacillus, Schleiferilactobacillus and Secundilactobacillus [20]. (In this review, we keep the names of the old classification of the genus Lactobacillus to avoid any confusion in the reader. However, the links for the appropriate name conversions are as follows: http://lactobacillus.ualberta.ca; http://lactobacillus.uantwerpen.be; http://lactotax.embl.de/wuyts/lactotax/). 
$\mathrm{LAB}$ are heterotrophic microorganisms, and have high nutritional requirements for amino acids and vitamins, because they have lost much of their biosynthetic potential in the process of evolution. For this reason, they only develop in nutrient-rich environments.

They ferment carbohydrates to almost entirely lactic acid (homofermentation), or to a mixture of lactic acid, carbon dioxide and acetic acid and/or ethanol (heterofermentation). Other compounds, such as diacetyl, acetaldehyde and hydrogen peroxide, are also produced. These compounds contribute to the flavor and texture of fermented foods, and may also contribute to the inhibition of undesirable microbes [22]. In addition to organic acids, LAB synthesize a wide range of beneficial metabolites, such as antifungal and anti-mycotoxigenic agents, bacteriocins and nutraceutical products.

The richness and diversity of microbial species, with their relative abundances and interactions, determine the establishment of distinctive and unique characteristics of each fermented product.

Despite common features, however, many differences exist with respect to substrates and products, and the types of microbes involved in the manufacture of fermented foods and beverages produced globally.

\section{European LAB-Fermented Cereals and Vegetables}

\subsection{Fermented Cereals}

In European countries, the fermentation of cereals is used mainly for the obtainment of bakery products (typical breads and sweet traditional leavened cakes) and for different beverages, including the ales and beers of northern Europe, the lagers of central and eastern Europe and numerous low or non-alcoholic beverages that contain a maximum of $0.5 \%$ volume of ethyl alcohol [23].

The most common and uncommon European products made from grains and obtained mainly by lactic acid fermentation are observed in Table 1. Regarding bakery products, most cereals like wheat, rye, barley, spelt and maize are fermented by natural fermentation (sourdough) or by adding commercial baker's yeast to leaven the doughs [24].

In Europe, countless different types of "Breads", including traditional typical breads [25-32], "Pizza" [33] and artisan sweet cakes as Italian "Panettone", "Pandoro" and "Colomba", are made by use of sourdough from mainly wheat and rye. In Portugal, maize flour is used in combination with rye flour to produce broa, a home-baked sourdough bread, still following ancient protocols [34-36]. In northern Europe, sourdough is employed especially in the baking process of rye flour, for example in Germany, the Baltic states and Russia [37-39]. Minor breads are produced by minor cereals such as spelt, maize or buckwheat [40-42]. Teff and teff sourdoughs are promising ingredients for bread production [43].

Sourdough is obtained by the fermentation of autochthonous microorganisms (bacteria and yeast) that are naturally present in the environment, or in raw materials or ingredients, conferring each sourdough a unique characteristic. Sourdoughs are characterized by more than 50 different species of lactic acid bacteria, but it is very likely that a non-identifiable and perhaps new sourdough LAB species exists [44].

In Europe, among fermented cereal products other than bakery products, different low and non-alcoholic cereal-based beverages have been developed. The development of cereal-based fermented beverages is in response to the growing prevalence in consumer vegetarianism, lactose intolerance, cholesterol content and economic reasons that are associated with dairy products. In fact, cereal-based beverages fermented with LAB could be a perfect alternative for people who are allergic to milk proteins [45]. Such products include "kvass" and "boza", which are cereal-based beverages traditionally made from fermented barley and rye malt, rye flour and millet flour. 
Table 1. Selected lactic acid bacteria fermented cereals and vegetables in Euro-Asia.

\begin{tabular}{|c|c|c|c|c|}
\hline \multicolumn{5}{|c|}{ A1. Fermented European Cereal Products } \\
\hline Fermented Product & Raw Material/Substrates & Country/Region & Lactic Acid Bacteria Species Mainly Found ${ }^{*}$ & References \\
\hline \multirow{5}{*}{$\begin{array}{l}\text { Bread, Pizza, Traditional } \\
\text { Sweet Cake } \\
\text { (Panettone, Colomba) }\end{array}$} & Wheat sourdough & $\begin{array}{l}\text { Italy, Greece, Spain, Germany, France, } \\
\text { Belgium, Portugal, Central } \\
\text { Europe countries }\end{array}$ & $\begin{array}{c}\text { L. acidophilus, L. alimentarius, L. amylovorus, L. brevis, } \\
\text { L. buchneri, L. casei, L. delbrueckii, L. farciminis, L. fermentum, } \\
\text { L. fructivorans, L. frumenti, L. johnsonii, L. mindensis, L. panis, } \\
\text { L. paralimentarius, L. plantarum, L. pontis, L. reuteri, L. rossiae, } \\
\text { L. sanfranciscensis, Leuc. citreum, Leuc. mesenteroides, Leuc. } \\
\text { pseudomesenteroides, Pc. pentosaceus, W. cibaria, W. koreensis, } \\
\text { W. confusa }\end{array}$ & [25-33] \\
\hline & Rye sourdough & $\begin{array}{l}\text { Germany, Serbia, Bulgaria, Finland, } \\
\text { Denmark, Norway, Sweden }\end{array}$ & $\begin{array}{l}\text { L. amylovorus, L. brevis, L. casei, L. curvatus, L. coryniformis, } \\
\text { L. farraginis, L. frumenti, L. helveticus, L. kimchii, } \\
\text { L. paralimentarius, L. paracasei, L. plantarum, L. pontis, L. panis, } \\
\text { L. sanfranciscensis, L. zymae, L. uvarum, Leuc. mesenteroides, } \\
\text { Ec. pseudoavium, Pc. acidilactici, P. pentosaceus, } \\
\text { W. paramesenteroides Lc. lactis }\end{array}$ & {$[37-39]$} \\
\hline & Buckwheat sourdough & Ireland, Poland & $\begin{array}{l}\text { L. gramninis, L. sakei, L. fermentum, L. vaginalis, L. crispatus, } \\
\text { L. gallinarum, W. cibaria, P. pentosaceus, Lc. holzapfelii, } \\
\text { L. brevis, L. curvatus, L. fermentum, L. pentosus, L. plantarum, }\end{array}$ & [41] \\
\hline & Spelt sourdough & Belgium, Italy & $\begin{array}{l}\text { L. rhamnosus, Pc. acidilactici, Pc. pentosaceus, } \\
\text { L. sanfranciscensis, Weissella spp. Leuconostoc spp. } \\
\text { L. brevis, L. fermentum L. gallinarum, L. helveticus, }\end{array}$ & {$[40,42]$} \\
\hline & Teff sourdough & Ireland & $\begin{array}{c}\text { L. plantarum, L. pontis, L. sanfranciscensis, L. vaginalis, } P \text {. } \\
\text { pentosaceus, Leuc. holzapfelii, W. cibaria }\end{array}$ & {$[41,43]$} \\
\hline Bread (Broa) & Maize sourdough & Portugal & $\begin{array}{l}\text { Leuconostoc spp, L. brevis, L. curvatus, Lc. lactis, E. durans, } \\
\text { E. casseliflavus, E. faecium, Str. equinus, Str. constellantus }\end{array}$ & [34-36] \\
\hline Trahanas & Wheat, sheep milk & Greece, Turky, Cyprus & $\begin{array}{c}\text { L. acidophilus, L. casei, Str. lactis, Str. diacetylactis, leuc. } \\
\text { cremoris, L. lactis }\end{array}$ & {$[46,47]$} \\
\hline Boza & $\begin{array}{l}\text { Barley, oats, rye, millet, wheat, } \\
\text { rice }\end{array}$ & Balkans (Turkey, Bulgaria) & $\begin{array}{l}\text { L. acidophilus, L. brevis, L. buchneri, L. coryniformis, } \\
\text { L. fermentum, L. graminis, L. parabuchneri, L. casei group, L. } \\
\text { lactis subsp. lactis, L. plantarum, L. paraplantarum, L. pentosus, } \\
\text { L. raffinolactis, L. sanfranciscensis, Pc. parvulus and pentosaceus, } \\
\text { Lc. lactis, Leuc. mesenteroides, Leuc. citreum, } \\
\text { W. paramesenteroides, Oenococcus spp. W. confusa, W. oryzae }\end{array}$ & [48-53] \\
\hline Kaera Kiesa & Sorghum, rice, millet & Estonia & & [54] \\
\hline Kile & Oat flour mixed water & Estonia & & [55] \\
\hline Bors (Borsh) & Rye or wheat bran & Romanian & L. amylolyticus L. fermentum, L. plantarum, L. casei, L. buchneri. & [56] \\
\hline Taar & Rye and barley, rarely also oats & Estonia & & [54] \\
\hline Kali & Malted cereals & Estonia & & {$[23,54]$} \\
\hline Kvass & Rye, barley malt & Russia & L. casei, Leuc. mesenteroides & [57-59] \\
\hline
\end{tabular}


Table 1. Cont.

\begin{tabular}{|c|c|c|c|c|}
\hline \multicolumn{5}{|c|}{ A2. Fermented European Vegetables Products } \\
\hline Fermented Product & Raw Material/Substrates & Country/Region & Lactic Acid Bacteria Species Used & References \\
\hline Fermented Olives & Green olives & Spain, Portugal, Italy & $\begin{array}{l}\text { L. casei, L. coryniformis, L. pentosus, L. plantarum, Leuc. } \\
\text { mesenteroides, P. pentosaceus, E. casseiflavous }\end{array}$ & [60-62] \\
\hline Hardaliye & $\begin{array}{c}\text { Grapes/mustard seeds/cherry } \\
\text { leaf }\end{array}$ & Turkey & $\begin{array}{l}\text { L. acetotolerans, L. brevis, L. casei, L. paracasei, L. pontis, } \\
\text { L. sanfranciscensis, L. vaccinostercu }\end{array}$ & {$[58,63,64]$} \\
\hline Fermented Sea Fennel & Sea fennel & Italy & & [65] \\
\hline Turnip shreds & Rapa & Italy (Brovada)Germany (Sauerruben) & $\begin{array}{c}\text { L. plantarum, L. hilgardi; } \text { L. coryniformis, L. maltaromicus, } \\
\text { L. viridescens, Pediococcus parvulus }\end{array}$ & [66] \\
\hline Sauerkraut & Cabbage & Europe & $\begin{array}{c}\text { L. brevis, L. plantarum, Leuc. mesenteroides, Pediococcus } \\
\text { cerevisiae, E. faecalis }\end{array}$ & {$[67,68]$} \\
\hline Fermented Pickles & Cucumbers & Europe, Poland & Lactobacillus spp., Leuconostoc spp., Pediococcus spp. & [69] \\
\hline Fermented Capers & Capers & Grece, Italy Spain & $\begin{array}{l}\text { L. plantarum, L. pentosus, L. fermentum, L. brevis, } \\
\text { L. paraplantarum, E. faecium, P. pentosaceus }\end{array}$ & [70] \\
\hline \multicolumn{5}{|c|}{ B1. Fermented Asian Cereal Products } \\
\hline Fermented Product & Raw Material/Substrates & Country/Region & Lactic Acid Bacteria Species Used & References \\
\hline Amazake & Rice & Japan & L. sakei & [58] \\
\hline $\begin{array}{l}\text { Fermented Rice-Noodle } \\
\text { (Kha nhom Jeen) }\end{array}$ & Rice & Thailand & $\begin{array}{l}\text { L. delbrueckii, L. crispatus, L. curvatus, L. lactis ssp. lactis, } \\
\text { Streptococcus spp. Bacillus subtilis, B. licheniformis }\end{array}$ & [71-73] \\
\hline Sourdough & Wheat & South Korea & $\begin{array}{c}\text { L. brevis, L. paralimentarius, } P \text {. pentosaceus, W. cibaria, Leuc. } \\
\text { citreum, W. koreensis }\end{array}$ & [2] \\
\hline Nombonchock & Rice & Cambodia & Various LAB species & [74] \\
\hline Chinese Steamed Bun & Wheat & Thailand & L. plantarum, L. casei & [75] \\
\hline $\begin{array}{l}\text { Comme (Sour Rice } \\
\text { Fermented Paste) }\end{array}$ & Rice & Vietnam & L. casei, L. paracasei, L. acidophilus, L. plantarum & {$[76]$} \\
\hline (2) & Einkorn & Turkey & $\begin{array}{l}\text { L. crustorum, Pediococcus spp, L. brevis, L. paraplantarum, } \\
\text { L. plantarum, L. fermentum, L. curvatus }\end{array}$ & [77] \\
\hline Tarhana & $\begin{array}{l}\text { Wheat flour, yogurt, vegetables, } \\
\text { spices }\end{array}$ & Turkey & $\begin{array}{l}\text { Lc. lactis, Leuc. mesenteroides, L acidophilus, E. durans, } \\
\text { Pediococcus spp., L. delbrueckii L. paracasei }\end{array}$ & [78] \\
\hline Tape Ketan & Glutinous rice, Ragi & Indonesia & Weissella spp, Pediococcus pentosaceus, Enterococcus sp & [79] \\
\hline Selroti & Rice-wheat flour-milk & India & Lactobacillus spp & [80] \\
\hline
\end{tabular}


Table 1. Cont.

\begin{tabular}{|c|c|c|c|c|}
\hline \multicolumn{5}{|c|}{ B2. Fermented Asian Vegetable Products } \\
\hline Fermented Product & Raw Material/Substrates & Country/Region & Lactic Acid Bacteria Species Used & References \\
\hline Naw-Mai-Dong & Bamboo shoots & Thailand & $\begin{array}{l}\text { Leuc. mesenteroides, } P \text {. cerevisiae, Lb. plantarum, Lb. } \\
\text { Fermentum, Lb. brevis }\end{array}$ & [81] \\
\hline $\begin{array}{l}\text { Chrourk Tror Sok, Chrourk } \\
\text { Sapei }\end{array}$ & Cucumber and cabbage & Cambodia & P. pentosaceus & [74] \\
\hline Burong Mustala & Mustard & Philippines & & \\
\hline $\begin{array}{l}\text { Pickled Vegetables } \\
\text { (Phak-Dong) }\end{array}$ & Cabbage & & B. siamensis $\mathrm{B} 44 \mathrm{v}$ & [6] \\
\hline Kimchi & $\begin{array}{l}\text { Cabbage, green onion, pepper, } \\
\text { ginger }\end{array}$ & Korea & W. cibaria, W. confusa, W. koreensis & [2] \\
\hline Suan-Cai & Vegetables & China & & \\
\hline Pao Cai & Cabbage & China & Leuc. mesenteroides, Lb. plantarum, Lb. casei, Lactococcus lactis & [2] \\
\hline Pak gua Dong & Mustard leaf & Thailand & Lb. plantarum & [72] \\
\hline Hom-Dong & Red onion & Thailand & & \\
\hline Jiang-Gua & Cucumber & Taiwan & & \\
\hline Dha Muoi & Eggplant & Vietnam & Lactobacillus fermentum, Lb. pentosus, Lb. brevis & [82] \\
\hline Dha Mиоi & Cabbage, various vegetables & Vietnam & Leuconostoc mesenteroides, Lb. plantatum & [72] \\
\hline Dиа Миоi & Mustard, beet & Vietnam & $\begin{array}{c}\text { Lactobacillus fermentum, Lb. pentosus, Lb. plantarum, } P \text {. } \\
\text { pentosaceus }\end{array}$ & [82] \\
\hline Dиа Chиа (Duа Mиоi) & Vegetables & Vietnam & $\begin{array}{c}\text { Lactobacillus fermentum, } L b \text {. pentosus, Lb. plantarum, } P \text {. } \\
\text { pentosaceus, Lb. brevis }\end{array}$ & [76] \\
\hline Fermented Mustard & Mustard & Vietnam & Lactobacillus fermentum, Lb. plantarum, Lb. brevis & [83]) \\
\hline Soibum & Bamboo shoot & India & & \\
\hline Soidon & Bamboo shoot tips & India & & \\
\hline Kanji & Carrot & India & & \\
\hline $\begin{array}{l}\text { Sunki, Tsuda-Turnip } \\
\text { Pickle }\end{array}$ & Leaves of Otaki-turnip & Japan & L. plantarum, L. brevis, B. coagulans, P. pentosacxeus & [84] \\
\hline Takuanzuke & $\begin{array}{l}\text { Japanese radish, salt, sugar, } \\
\text { Shochu }\end{array}$ & Japan & $\begin{array}{c}\text { L. acetotolerans L. brevis, L. casei, L. collinoides, L. curvatus, } \\
\text { L. fructivorans, L. namurensis, L. sakei L. delbrueckii, } \\
\text { L.fermentum, L. plantarum, L. citreum, Pc. pentosaceus, Pc. } \\
\text { damnosus }\end{array}$ & [84] \\
\hline Sinki & Radish tap-root & India & Lb. brevis, $L b$. plantarum, $L b$. fermentum & [85] \\
\hline Oiji & Cucumber, salt, water & Korea & & [86] \\
\hline Sayur Asin & $\begin{array}{l}\text { Mustard leaves, cabbage, salt, } \\
\text { coconut }\end{array}$ & Indonesia & & \\
\hline Tsukemono & Pickled vegetables & Japan & $\begin{array}{l}\text { L. brevis, L. namurensis, L. acetotolerans, L. sakei, L. curvatus, } \\
\text { L. collinoides, L. fructivorans, L. casei, L. casei subsp. } \\
\text { pseudoplantarum, L. delbrueckii, L. fermentum, L. plantarum, } \\
\text { L. citreum, Pc. pentosaceus, Pc. damnosus }\end{array}$ & [84] \\
\hline
\end{tabular}

http://lactobacillus.ualberta.ca; http://lactobacillus.uantwerpen.be; http://lactotax.embl.de/wuyts/lactotax/). 
"Kvass" is a cereal-based beverage traditionally made from fermented barley and rye malt, rye flour and stale rye bread that is mainly produced in eastern countries such as Russia and Poland, and Baltic countries, especially Lithjuania and Latvia [57]. It is a non-alcoholic beverage that contains $1 \%$ or less alcohol. The microflora of kvass fermentation is normally composed of yeasts (Saccharomyces cerevisiae) and LAB such as Lactobacillus casei and Leuconostoc mesenteroides [58,59]. As it is a product of lactic and alcohol fermentation, it does not require pasteurization and, therefore, contains LAB, which are useful microflora for human health. Therefore, kvass can be considered as a probiotic beverage. Different authors showed that Kvass eliminates flatulence, hyperacidity and other digestive disorders and, at the same time, has a positive effect on metabolism, increases the bioavailability of calcium and other minerals, and possesses antioxidant properties [45].

Another traditional ancient fermented cereal, produced in different East European, countries is "Boza", a cereal beverage that is obtained from the fermentation of whole grain or flour of different cereals (usually millet, barley, oats, maize, rye, wheat or rice), but boza of the best quality and taste is made of millet flour. It is very popular in Turkey, Albania, Bulgaria, Macedonia, Montenegro, Bosnia and Herzegovina, and parts of Romania and Serbia, as well as in South Russia. It is a viscous low-alcoholic drink with a pleasant sweet taste and slightly acid flavor, varying in color from creamy-white and beige to light brownish [48].

Due to boza's pleasant flavor and taste and high nutritional value, it has become a very popular drink consumed daily by people of all ages. The compositional variations of boza samples result from the utilization of different types and amounts of cereals as raw materials, and uncontrolled fermentation conditions [49].

The microbiota responsible for the fermentation of Boza seem to be particularly heterogeneous, including both homo- or hetero-fermentative LAB (L. plantarum, L. brevis, L. fermentum, Leuc. mesenteroides, L. casei, L. acidophilus, etc), which provide the acid character of boza, and yeasts responsible for alcohol fermentation [49-52]. It is a highly nourishing drink, which is easily digestible, gratifying in taste and fragrance, and exerts beneficial effects on human health due to its probiotic microbial content.

"Trahanas" is one of the most popular fermented milk-cereal products from Greece and Cyprus, and it is named 'Tarhonya' or 'Talkuna' in Hungary and Finland, respectively. It is produced during summer, mainly from whole fresh ewes' and goats' milk or a mixture of them. Sometimes, instead of milk, a pulp of vegetables is used. For the production of trahanas, fresh milk is allowed to be acidified for some days either spontaneously or by adding a culture of yoghurt [46]. Fermentation of trahanas is important for the development of the product's flavor and aroma, which are mainly produced by Streptococcus lactis, Str. diacetylactis, Leuc. cremoris, L. lactis, L. casei, L. bulgaricus and L. acidophilus [47]. Trahanas is stirred every day until it reaches the desired acidity. It is then heated, followed by the gradual addition of ground wheat and salt. Sometimes eggs are also added and the final product is called "sour trahanas with eggs". Methods for the preparation of such products vary from place to place, but cereals and fermented milk are always the two major components [46]. Trahanas is a product with high dietary fiber content mainly due to the wheat used for its production. Greek 'Trahanas' is a very nutritive food as it is a good source of proteins, minerals and other nutrients, and is used largely for feeding people.

Another wheat bran-based fermented beverage is "Borş", traditionally prepared in Romania. It is used to give a sour taste to traditional soups or consumed as a refreshing drink. It has many health benefits, especially due to the high vitamin and mineral contents. Information about Romanian borş is scarce, mainly restricted to travel guides and cooking books, as this fermented beverage did not receive any scientific attention before this decade.

Romanian borş was investigated for the first time regarding its microbiological and physicochemical characteristics by Grosu-tudor [56], who showed that Romanian borş fermentation was mainly carried out by lactobacilli, among which L. amylolyticus was the most frequently found LAB species. Other lactobacilli frequently found were L. fermentum, L. plantarum, L. casei and L. buchneri. 
The fermentation of wheat bran during the production of borş leads to increased concentrations of available amino acids and phenolic compounds. Borş is a good revitalizing product, which was always used for its perceived beneficial effects on respiratory diseases, digestive problems (indigestion, vomiting), liver and bile diseases, and even cancer treatment.

There are many other cereal-fermented products typical of the traditions of the East European countries, still little studied. Historically, several low-alcoholic drinks were made in Estonia such as "Taar" and "Kali". "Taar" is made of rye and barley, rarely also oats. Grains are milled into flour and mixed with boiled water. The beverage has to turn sour for 2-3 days, and the resulting drink is "taar". To prolong the preservation of taar and to add specific taste, aromatic species (like Origanum vulgare and Ledum palustre) are added during the fermentation process [54].

"Kali" is another alcohol-free drink from Estonia. Its technology is similar to that used to make taar, but it is made of malted cereals and produced after the beer was already made. It's like a mix between a beer and a cola, with a sour-sweet taste, a natural fizz, and very low alcohol content [23].

Furthermore, there are other uncommon (and endangered) preparations from fermented cereals. Different fermented dishes and drinks made of oat were widely consumed as regular meals in Estonia until the end of 19th century, and sporadically until the middle of 20th century, but nowadays their popular use is limited to special groups trying to restore national food heritage. For example, oat seeds were macerated in warm water, left to ferment for a few days, and then the milky water was squeezed out and the resulting sour liquor, called "kaera kiesa" or "kaerapiim", was drunk on the side of the meal [54].

A bit of a different beverage, called "kile", was made of oat flour mixed with water; it was let to stay in warmth for a night. This filtered sour beverage was consumed instead of sour milk on the side of the meal. If the filtrate was boiled, it became a kind of gruel, which was also called kile, but also "kiisel" or "kisla", and eaten hot with butter or fat, or later as a cold jelly. Similar gruels (also similarly named) were prepared from rye or from rye and potatoes [55].

\subsection{Fermented Vegetables}

In Europe, a total of 21 different vegetables are fermented, in addition to an unspecified number of variably composed vegetable blends and fermented vegetable juices [87]. Most vegetables or their juices will undergo a spontaneous lactic acid fermentation when conditions are anaerobic and moisture levels, salt concentrations and temperature are appropriately adjusted so that the lactic acid bacteria have a competitive advantage [88].

Most fermented vegetables typical of European countries such as pickles, capers, cucumber, sea fennel, turnip shreds and hardaliye are still fermented on a small scale, either in the home as side dishes or as ingredients. Instead, "table olives" and "sauerkrauts" are the major fermented vegetables produced in western countries, are of significant commercial importance and will be treated in depth in this paragraph (Table.1).

"Table olives" are a traditional food of the Mediterranean countries (Spain, Greece and Italy, mainly in Sicily), with many centuries of history. They are prepared with fruits obtained from cultivated Olea europaea subsp. europaea var. europaea trees, and their production has expanded to many countries around the world $[60,61,89]$.

After harvest, olives are inedible due to bitterness, and have to be processed to remove the fruit bitterness by hydrolysis of the phenolic compounds, especially oleuropein.

Globally, there are three main methods of obtaining table olives: Spanish- or Sevillian-style green olives in brine; Californian-style black ripe olives and Greek-style natural black olives in brine. However, there are many other traditional table olive elaboration recipes, which are less known in the international market [90] and constitute niche products, such as table olives produced in Sicily, that do not undergo preliminary treatment in sodium hydroxide (lye) before fermentation [91].

All methods rely on the autochthonous or indigenous microbiota for fermentation, with LAB and yeasts as the primary organisms. Lactic acid bacteria are involved in the fermentation of Spanish-style 
treated olives, while yeasts are responsible for the fermentation of Greek and Californian processed black olives, with LAB representing a small proportion of the total microflora [92].

Lactic acid bacteria, which convert fermentable sugars to lactic acid and other organic acids depending on their metabolic pathways, are the most important group of bacteria in olives [62]. LAB fermentation of olives reduces their $\mathrm{pH}$, provides microbiological stability and extends their shelf life.

Together with $\mathrm{LAB}$, yeasts play a substantial role in fermented olive production, contributing to the determination of their aroma and taste due to the production of desirable metabolites and volatile compounds, while at the same time they enhance the growth of LAB and degrade phenolic compounds [93,94].

Different studies highlighted that the use of selected starter cultures, and more particularly the use of autochthonous LAB strains isolated from a spontaneous fermentation of the respective olive cultivar, could lead to a more controllable fermentation resulting in a product of high and constant quality, which is safer for the consumers and has a longer lifetime, and this process also influences the volatile organic compounds (VOC) profiles of olives [95,96].

Like table olives, "Sauerkraut", primarily from cabbage, is one of the most well-known varieties of fermented vegetables associated with central and eastern European cultures, though it can be found in western European cuisine as well. For this product, the crucial importance of LAB fermentation has also been confirmed.

In fact, though the microbial composition of sauerkraut can vary during the initial stages of fermentation, appropriate fermentation conditions, such as temperature and relative ingredient concentration, ensure that $\mathrm{LAB}$ are the dominant microorganisms in the final fermented product. Zabat et al. [67] highlighted that although LAB exhibit low relative abundance in the starting ingredients, and in the production facility environment, they are able to dominate the fermented sauerkraut, confirming the high capability of LAB to cope with the strong selective pressures of high salinity and acidity during fermentation with respect to other microorganisms.

LAB guarantee the success of cabbage fermentation by the production of organic acids, bacteriocins, vitamins and flavor compounds responsible for many of the characteristic sensory qualities of the final fermented products, including extended shelf life. Moreover, numerous LAB isolated from sauerkraut were found to be probiotic or putative probiotic cultures [68,97].

Several other varieties of vegetables (such as carrots, French beans, marrows, artichokes, capers and eggplants), which are mainly cultivated in southern Italy or, more generally, in the Mediterranean area, may increase their safety, nutritional, sensory and shelf-life properties through lactic acid fermentation under standardized industrial conditions [98].

Among these minor fermented products occurring in the European countries are "caper", "sea fennel", "turnip shreds" and "cucumber", regarding which few scientific studies have yet been carried out, focusing on their microbial communities and population dynamics during lactic acid fermentation.

For example, "Caper" berries are the fruits of Capparis species (mainly Capparis spinosa L.), a Mediterranean shrub cultivated for its buds and fruits.

The main producers of fermented caper berries are Mediterranean countries, especially Greece, Italy, Turkey, Morocco and Spain, and the final products are exported mainly to central European countries, the United States and the United Kingdom as a delicatessen product [99]. The fermentation of caper fruits is often done by traditional artisanal ways. Fruits are harvested during June or July, immersed in tap water, and subjected to spontaneous lactic acid fermentation for ca. 5-7 days at ambient temperature, which may markedly vary from $23^{\circ} \mathrm{C}$ to $43^{\circ} \mathrm{C}$. Subsequently, fermented capers are placed into brine and distributed for consumption. L. plantarum is the main species, which is isolated from the brine of capers [100].

"Sea fennel", known as maritime rock (Crithmum maritimum L.), is a salt-tolerant plant, widely grown in maritime rocks and more rarely sandy beaches in Mediterranean countries and Atlantic coasts. This plant has several usage areas such as culinary, medicine and cosmetics because of the 
content of the nutrients and phytochemicals. In the Mediterranean region, their leaves are consumed fresh or fermented as salad or with yoghurt [65].

Fermented "turnips" are a traditional food in both Asia and Europe. In Korea, turnips are used in a form of kimchi whereas, in Europe this is a traditional fermented vegetable produced mainly in Germany (known as sauerruben) and in the northeast Italian region (known as Brovada).

Brovada is obtained by natural fermentation of turnips (Brassica rapa). It is similar to sauerkraut, but in some aspects the technology of production is different. Turnips are cleaned and put in vats, alternating them with layers of grape skins. Before covering the vat, a mix of water and salt or water only is added. The fermentation is a spontaneous process caused by the microorganisms present on the various components (turnip and grape skins) and goes on for about 30 days. After that, the turnips are extracted from the vats, peeled, cut into pieces and wrapped up in plastic bags ready for selling. The product is generally eaten after cooking, but sometimes even raw [66].

Another fermented vegetable, produced both in Asia and Europe, is the "Cucumber". Considering that fresh cucumbers expire relatively fast, they are most frequently eaten as fermented pickles. Fermented pickles are products stabilized with salt and lactic acid, which are produced by lactic acid bacteria fermentation. They can be produced in different ways. In the northern parts of Europe, especially in Poland, cucumbers are fermented in the presence of dill weed, garlic, blackcurrant and oak leaves and horseradish at a final brine concentration of 3-4\%. Spices give the products a desirable flavor, and antimicrobial substances present in them prevent mold and yeasts growth. The cucumbers are not desalted and they have to be stored at $0-5{ }^{\circ} \mathrm{C}$ [101]. Lactobacillus spp., Leuconostoc spp. and Pediococcus spp. are the main LAB naturally present on the cucumber surface and responsible for fermentation [69].

Another non-alcoholic fermented beverage produced in a traditional way in Thrace, the European part of Turkey, is "Hardaliye". Hardaliye is a lactic acid-fermented traditional beverage produced from grape juice and crushed grapes, with the addition of different concentrations of whole/ground or heat-treated mustard seeds and sour cherry leaves [63]. The predominant LAB species found in hardalyie are L. paracasei subsp. paracasei and L. casei subsp. pseudoplantarum, followed by L. pontis, L. brevis, L. acetotolerans, L. sanfranciscensis (formerly known as L. sanfrancisco) and L. vaccinostercus [64].

\section{LAB-Fermented Cereals and Vegetables of Asian Origin}

\subsection{Fermented Cereals}

In Asia, especially in China, Japan, Korea and other Far East regions, where pastoral agricultural practices and animal husbandry are more limited, fermented foods that evolved were based more often on rice and grains, soybeans, vegetables and fish as the primary substrates [102].

Lactic acid fermentation of cereals is a long-established processing method and is used in Asia for the production of foods in various forms, such as (semi)-solid cooked dough, gruels, porridge and liquid beverages.

Although differences exist between countries, processing the cereals may involve soaking, heating, mashing, filtering and backslopping. In general, cereals are soaked in water for a couple of days to soften the grains for easier crushing and wet-milling into slurry, from which hulls, bran particles and germs can be removed by sieving procedures. During the slurring or doughing stage, which lasts for 1 to 3 days, mixed fermentations including lactic acid fermentation take place [103].

In Asia, the main fermented cereals are millet, maize, barley, oats, rye, wheat, rice and sorghum, easily fermented by naturally occurring microorganisms. In particular, rice and soybean are the commonest foods in Asia, and are popularly fermented. In Table 1 are the main popular LABfermented cereals of Asian origin.

Rice noodles, called "Nombonchock" in Cambodia or "Khanom jeen" in Thailand, are made by lactic acid bacteria fermentation, which gives them a low fermented odor, flexibility and smoothness [71-73,104,105]. 
For these rice noodles, broken rice grains, usually stored/fermented over a six-month period, are naturally fermented for a few days, wet milled, and then left to precipitate as rice flour, which is then placed in a cotton bag under an applied weight for excess water removal. The fermented rice flour is then pre-cooked, kneaded and extruded into noodles in boiling water, and is immediately cooled and dried [106].

Fermentation in nombonchock/khanom jeen is achieved by lactic acid bacteria acting on the lipid, protein and ash contents to enhance the stringy mouth feel of the noodles, and a number of volatile compounds such as 3-methylbutanoic acid and diacetyl, 2-methylpropanoic acid, are synthesized by the metabolic activities of these microorganisms, which impart a characteristic flavor to nombonchock/khanom jeen [107].

"Amazake" is a Japanese fermented sweet food beverage prepared from rice.

There are two types of amazake depending on the preparation method: a low-alcoholic drink made with lees left from sake (sakekasu amazake) and a non-alcoholic drink made with koji rice that can be enjoyed by everyone including small children (koji amazake, in Japanese).

Koji rice is cooked rice that has been inoculated with Aspergillus oryzae, a mold that is widespread in Japan. It is at the heart of many different Japanese ferments. It is used to make miso, sake, amazake, rice vinegar, soy sauce and mirin [108]. In either of the preparation methods, the mixture is allowed to ferment for 6-8 h, thereby leading to saccharification and conversion of the rice starches into glucose and oligosaccharides. The rice's vitamins and amino acids also become converted into an easily digestible form. There is no dairy or gluten in amazake, and it may serve as a natural sweetener in the production of other traditional drinks.

Amazake is a sake precursor and known for its health benefits, including weight loss and stress relief, positive skin effects, innate immunestimulating activity, antihypertensive effects, cholesterol lowering effects, and tyrosinase-inhibiting activity [108-111]. Amazake is rich in functional ingredients including vitamin B, glucoses and amino acids, as well as fermentation products of rice malt fungi [112]. The non-alcoholic amazake is used as a baby weaning formula due to its ease of digestion. Recently, L. sakei strains (UONUMA 1, 2 and 3) were reported as crucial for the promotion of amazake's nutritional, sensorial and functional properties [113].

Further, "Com me" is a sour rice fermented paste, a Vietnamese traditionally fermented food. It is a sour fermented paste made from overcooked wet rice fermented in clean and tightly closed containers for 7-10 days. Sometimes, the fermented product from a previous batch is added to the present batch to expedite the souring process (backslopping). During fermentation, rice changes from the whole grain state to a macerated product, and finally to a milky cream substance with a light sour aroma. After fermentation, the product is crushed and sieved. Com me is used as a souring agent during cooking and gives a meal a specific flavor and sour taste [76]. The presence of L. plantarum, L. paracasei, L. casei and L. acidophilus species was found in "Com me" samples from provinces along the Mekong river delta (South Vietnam).

Another traditional Asiatic cereal-fermented food is "Tarhana". It is a traditional Turkish food prepared by mixing wheat flour, yoghurt and some vegetables and spices, followed by fermentation, drying and grinding [114].

It is a good source of nutrition for children and the elderly, since it provides increased digestibility and nutritional value due to its high bioactive proteins and prolonged fermentation process $[16,115,116]$. Generally, tarhana mix is fermented by the natural microbial flora of the flour and other ingredients included. The dough of Tarhana is prepared after 1-7 days' lactic and alcoholic fermentation. Thereafter, the dough is sun-dried and ground. Traditionally, the grounded dough of Tarhana is used to make soup. The characteristic taste and flavor of Tarhana are derived from lactic acids, ethanol, carbon dioxide, and some organic compounds produced by LAB and yeast. Kivanc et al. [78] found various species of yeast and lactic acid bacteria occurring in Tarhana during natural fermentation. They observed that Lactococcus lactis spp. lactis, Leuc. mesenteroides, L acidophilus, Enterococcus durans, Pediococcus spp., L. delbrueckii ssp. lactis and L. paracasei bacteria played important roles in the fermentation of 
Tarhana dough. Furthermore, Kluyveromyces marxianus, Yarrowia lipolytica, Pichia membranaefaciens, Pichia mexicana, Pichia angusta, Debaryomyces hansenii, Candida sorboxylosa, Candida fluviatilis and Saccharomyces cerevisiae were identified during Tarhana fermentation.

There are several products similar to Tarhana in European countries. They are known as Thanu in Hungary, Trahanas in Greece and Talkuna in Finland.

Further, "Boza" is a traditional Turkish beverage made by the fermentation of millet, cooked maize, wheat or rice semolina/flour. Two different types of fermentation occur simultaneously during boza fermentation. In one, alcohol fermentation produces carbon dioxide bubbles and increases the volume. The second is lactic acid fermentation, which produces lactic acid and gives the acidic character to boza. In either of the two fermentative processes, the cereals are boiled for $1-2 \mathrm{~h}$, cooled and strained. Sugar is then added before fermentation for up to $24 \mathrm{~h}$. Apart from the yeasts present, Lactobacillus, Micrococcus, Leuconostoc and Streptococcus genera are the commonest LAB used [117].

Boza is a thick liquid, pale yellow in color with a characteristic acidic-alcoholic odor, and it is a favorite drink, particularly on cold winter nights. It is a healthy and nutritious beverage, and its lactic acid content has positive effects on digestion and intestinal flora [21,118]. A previous report on an improved sensory version of boza was associated with Leuc. mesenteroides and L. confusus as the main fermentative LAB species [53].

There are also similar beverages to boza that are produced in East European countries, known as braga or brascha, as well as in the Balkan region, also known as boza.

Tape ketan (fermented glutinous rice) and tape singkong (fermented cassava) are traditional Indonesian foods produced by fermenting carbohydrate sources using ragi as the starter culture [79]. Mold, yeast and bacteria have their own roles in developing the characteristics and flavor of tape. The LAB found in tape are Weissella spp, Pediococcus pentosaceus and Enterococcus spp [119].

Tape ketan is a sweet alcoholic drink similar to the sweet Japanese sake. The alcoholic content could be as high as $10 \%$ and largely depend on fermentation time. Its production involves boiling glutinous rice, cooling and inoculation with crushed ragi yeast cake or other desired LAB, and then fermented for 1-3 days.

Selroti is a Nepali sweet rice bread, mostly made and eaten during the Hindu festivals of Dashain and Tihar that take place in Nepal and some parts of India. The preparation involves the addition of milk, water, cooking oil, sugar, ghee, butter, cardamom, cloves, bananas and other flavors to a semi-liquid rice flour dough, which are thoroughly mixed, allowed to ferment for between 4 and $24 \mathrm{~h}$, and fried.

Yonzan and Tamang [80] reported Leuc. mesenteroides, E. faecium, Pc. pentosaceus and L. curvatus as the predominant LAB found in selroti, alongside other yeasts. They also reported that Leuc. mesenteroides is the most prevalent $\mathrm{LAB}$ in selroti batters.

Moreover, in different Asiatic countries, wheat is widely used to produce sourdough-based products. In fact, dough for the various flat breads (e.g., naan, pita and kirsa) made in parts of Asia, as well as dough for the production of steamed bread in East Asia, is fermented in a process resembling that used for sourdough bread in Europe [120]. Furthermore, einkorn sourdough is commonly used to produce tasty breads [77].

The Chinese steamed bun also called baozi is a traditionally fermented wheat product originating from China, but it is consumed in many other countries in Asia. The bun has been a staple food for more than 2000 years [121], and is broadly classified into two types. The first needs starter dough for fermentation, just like sourdough, while the second type requires baker's yeast. The production of Chinese steamed buns from starter doughs requires the addition of wheat flour and water to the starter dough, and fermentation for 16 to $20 \mathrm{~h}$. The fermented dough is mixed with other ingredients (flour, water, sugar and leavening agents), shaped as a bun, stuffed and then steamed [75]. The steaming process makes it differ from oven-baked sourdough or other bread products in Europe, which gives it a thin smooth white skin, rather than the thicker brown crust of western oven-baked breads. More than 
thirty LAB were reportedly isolated from this fermented cereal product, which alter its taste, texture, and nutritional and functional qualities [75].

\subsection{Fermented Vegetables}

Asians generally are lovers of fermented food products, particularly Southeast Asians.

Fermented vegetables such as Inziangsang, Kimchi, Pak-Gard-Dong, Khalpi, Dakguadong, Jiang-gua, Burong mustala, Gundruk, Ca muoi, Soidon, Suan-tsai, Sayur asin, Paocai, Sauerkraut, Nozawana-Zuke, Yan-jiang and Yan-tsai-shin are habitually consumed by Thai, Indian, Chinese, Vietnamese, Japanese, Korean and Taiwanese people [6,82,122-130].

Most traditional preparatory and fermentation processes are kept secret, and are passed on from generation to generation in tribes and castes in different provinces, while many of them are made at the home scale using backslopping [131]. Different kinds of vegetables are also fermented, mainly by mixing with salt for a few hours and then adding rice-wash water (to accelerate fermentation time and to get an attractive color), to be eaten the following day [105].

Most of the vegetable fermentations occur spontaneously and provide conditions that favor the growth of LAB and inhibit undesirable microorganisms [105]. Lactic acid bacteria fermentation disrupts the mechanism of spoilage microorganisms via the oxidation of carbohydrates to carbon dioxide, alcohol and organic acids [132]. This in turn helps in the prevention of some diseases like diarrhoea and cirrhosis, while the antioxidants in fermented vegetables can aid in eradicating harmful free radicals that act in the developmental process of degenerative diseases [16,130].

The fermented vegetables in Asia are numerous. In this review, just the most widely consumed will be described in depth (Table.1). In Korea, a popular lactic acid bacteria fermented vegetable called "Kimchi" is widely consumed. It is traditionally prepared by immersing cabbage in a pool of vast ingredients including fish sauce, spices and radishes. This is followed by fermentation with various strains of LAB and other microorganisms, and it is consumed raw globally $[16,133]$. Kimchi is reported to reduce hte risks associated with carcinogenesis, atherogenesis, oxidation, tumors, bacterial infections, obesity, inflammation, mutagenesis and cancer, in addition to slowing aging, lowering cholesterol, stimulating the immune system, and containing probiotics [16,134].

"Sinki", a non-salted fermented radish taproot product, is traditionally consumed as a base for soup and as a pickle in some north-eastern states of India, in Nepal and a few places in Bhutan [85]. Sinki is a preserved Nepali fermented vegetable prepared from radish tap roots. It usually takes about a month of bacterial curing, followed by drying in the sun and storage. Production involves wilting the radish tap roots, cutting off the leafy tops and shredding the radish tap-root sections. If it is for pickling purpose, the radish is just cut up, and left to ferment in a 2-3 foot hole above a small fire. The fire is later quenched after enough warmth is attained, replacing the bottom with bamboo, straw and further fortifications such as more vegetation, boards, rocks and mud to create a mostly air-tight barrier. Fermentation takes 20-30 days, followed by sun-drying, before it can be eaten.

If it is consumed as a pickle, drying is not required; rather, sinki is mixed with spices and bottled. Tamang and Sarkar [85] reportedly found numerous strains of L. plantarum, L. brevis and L. fermentum to be the predominant $\mathrm{LAB}$ in the fermentation of sinki.

Fermented cucumbers are produced both in Europe and Asia. Fermented cucumbers are turned into a product called jioang-gua in Taiwan, khalpi in Nepal and India, paocai in China, or oiji in Korea, and are referred to as pickles in many parts of the United States, Europe (Russia, Ukraine) and Canada [86]. Most cucumbers are fermented in a salt solution. Cucumber fermentation relies on the presence of naturally-occurring LAB or, in some cases, inoculum from a pure starter culture.

Thai pickled vegetables (Phak-dong) fermented with B. siamensis B44v are also consumed in Thailand [135]. These traditional fermented foods are obtained by the fermentation of naturally occurring LAB, such as L. casei, L. plantarum, L. brevis, L. pentosus, L. fermentum, L. paracasei, Weissella koreenis, W. confusa, W. cibaria, Leuc. kimchi, Leuc. mesenteroides, L. fallax, Enterococcus 
and Pediococcus species [6]. The lactic acid bacteria-mediated fermentation of vegetables is a standard method for the preservation and advancement of their dietary and sensory characteristics [70].

"Tsukemono" refers to Japanese pickled vegetables that are traditionally fermented with salt and seasonings for the purpose of shelf-life-extension, as well as taste and flavor enhancements. Preparation involves washing and direct pickling in nukadoko (a mix of rice bran, salt, seasonings and water), with proper mixing to effect anaerobic fermentation balance. Microbial growth activation takes more than 7 days, and the microbes that are involved in the fermented vegetables are mainly lactic acid bacteria, including L. brevis, L. namurensis, L. acetotolerans, L. sakei, L. curvatus, L. collinoides, L. fructivorans, L. casei, L. casei subsp. pseudoplantarum, L. delbrueckii, L. fermentum, L. plantarum, L. citreum, Pc. pentosaceus and Pc. damnosus [84].

In addition, "Miang" is a fermented Thai vegetable. The production involves steaming Thai tea leaves, which are then wrapped tightly and packed in a container. The leaves are pressed tightly under a heavy weight covered with banana leaves and fermented for 4-7 days, or even up to a year depending on the maturity of the tea leaves [81].

The fermented product is similar to Myanmar's lak hpak, and is famous in northern Thailand. It is usually consumed together with peanuts, ginger, garlic or roasted coconut sliced as a side dish [81]. The main microorganisms involved in the fermented products include the genera Lactobacillus, Streptococcus and Leuconostoc, as well as several other members of the LAB group.

\section{Prospective Studies and Considerations}

Generally safe, high-quality and acceptable ethnic and traditional fermented cereals and vegetables are important because they have eminent roles in the traditions, histories, and social and economic activities of Euro-Asian cultures and peoples. The fermented food products may be significantly improved using commercial starter cultures such as LAB, except that current molecular and technological developments provide much better and faster prospects, with increased accuracy and sensitivity. The culture-independent methods are critical for investigating the metagenomic compositions of diverse and complex microbial communities within fermented food products. Available databases serve as match references to microbial DNA sequences, ascertaining individual microbes' identity and potential [2]. A combination of DNA sequencing with bioinformatics provides useful identity characterization of an organism in a more rapid and accurate way.

Metagenomics and metatranscriptomics, although still underexploited, promise to uncover the functionality of complex microbial consortia directly in the food matrix, and understand microbial behavior in response to different process conditions [136]. In metagenomics or metatranscriptomics studies, no PCR is performed, and total DNA or cDNA is sequenced. Metagenomics analysis allows the obtaining of the taxonomical composition of the community, and the abundance of all microbial genes. The potential activities of the microbial communities are highlighted, because a specific gene may not be really expressed in that condition, or because DNA may arise from dead or metabolically inactive cells. In order to identify the genes actually expressed in a food sample, RNA sequencing (RNA-seq) is the most appropriate path to take, which is what happens in metatranscriptomics [136].

Metatranscriptomics is currently being considered as an option for doing an in-depth investigation into gene expressions of fermented foods' microbial communities. The results may be coupled with other 'omics'-based approaches, including proteomics and metabolomics, for a much deeper insight into the interactions of the microorganisms in association with the organoleptic and physicochemical properties of fermented foods [2].

Using a combination of 16S rRNA sequencing with tricine-sodium dodecyl sulfate-polyacrylamide gel electrophoresis (tricine-SDS PAGE), certain fermented foods from Cambodia were determined to contain bacteriocin-producing LAB [74], and the bacterial diversity of kefir drinks from Bosnia and Herzegovina was obtained through rRNA gene amplicon sequencing by Garofalo et al. [137]. Denaturing gradient gel electrophoresis (DGGE) methods are now used to screen and identify fermented foods' microbiota, such as the LAB in Italian sourdoughs [25] and boza [48]. Pla-som and nem chua, 
Thai sour fermented fish and Vietnamese pork sausage, respectively, were investigated with these techniques $[138,139]$.

Ribosomal DNA sequencing, and molecular typing by random amplified polymorphic DNA (RAPD) techniques, are other methods used in the determination of the LAB and other bacterial strains in fermented foods such as nham [105] or boza [48].

Similarly, restriction fragment length polymorphism (RFLP) analysis of $16 \mathrm{~S}$ ribosomal DNA (rDNA) is a potential tool for the overall screening of the LAB-fermented cereals and vegetables in Euro-Asia and globally, as it was successfully employed in the identification of LAB used as starter cultures for sensorial, aroma and product quality studies involving Thai fish sausage [140].

Another version of RFLP, terminal restriction fragment length polymorphism (T-RFLP), in conjunction with $16 \mathrm{~S}$ rRNA gene sequencing may be utilized with broad potential in the investigation and analysis of LAB-fermented cereals and vegetables, because it was useful in determining LAB starter cultures for gamma-Aminobutyric acid (GABA) accumulation in Myanmar fermented fish with boiled rice [141].

Other LAB identification methods, such as mass spectrometry (ESI-TOF MS) and matrix-assisted laser desorption/ionizing time-of-flight mass spectrometry (MALDI-TOF MS), can play very important roles in identifying the diversity of native lactic acid bacteria in Euro-Asian fermented cereals and vegetables, as found in selected Vietnamese and Thai fermented foods [83,142]. Metagenome shotgun sequencing and metabarcoding also have been used to detect the pathogens and virulence factors in fermented foods [143].

It should be considered that LAB starter cultures need constant enhancements, which can ensure better-defined and -characterized strains meant for cereals and vegetables fermentation, and in turn lead to the production of functional fermented food products with sensorial qualities [2].

Further, due to some local or small-scale production of the fermented products, unhygienic processing conditions are not uncommonly associated with them, thereby attracting pathogens with diverse contaminating avenues, ranging from vessels used, to raw materials and acidophilic pathogens. These health risks require cogent investigations. Other than LAB, some pathogens may be present to release harmful toxins in the fermented cereals and vegetables, such as mycotoxins, which are more common in tropical Southeast Asia.

Ashaolu [2] highlighted that natural anti-nutritional elements, such as protein inhibitors, cyanogenic glycosides, phytates, saponins, oligosaccharides, lectins and tannins, as well as biochemical residues, in most raw materials used in food fermentation should be monitored properly for their nutrient content and safety. In the same vein, several Euro-Asian traditionally fermented beverages have not been thoroughly investigated for their alcohol content levels, which the modern-day consumer is interested in.

\section{Conclusions}

There is a global demand for functional foods, and a cheap and green biotechnological means of attaining this is fermentation. Foods, especially cereals and vegetables, fermented with lactic acid bacteria offer valuable health-promoting functions to consumers. Europe and Asia have long and huge traditions in the manufacture of several LAB-fermented foods, and LAB starter culture improvement can aid in increasing the hygiene, safety and quality of fermented products.

The use of diverse microbial strains, especially LAB groups, in the production of fermented cereals and vegetables can provide socio-economic benefits and several other prospective merits. Other than culture-dependent LAB fermentation, bioinformatics coupled with DNA sequencing methods are providing clearer insights into the make-up of the LAB metatranscriptomics, in order to decipher the relationships between fermented cereals and vegetables and $L A B$, and their products' sensory qualities. The small scale and local production of several Euro-Asian LAB-fermented foods imply that their characterization, safety and hygiene must be improved. 
Author Contributions: Conceptualization, writing-original draft preparation, writing-review and editing, supervision, A.R. and T.J.A. These authors contributed equally to this work. All authors have read and agreed to the published version of the manuscript.

Funding: This research received no external funding.

Acknowledgments: This study was supported by the Project PRIN 2017 “The Neapolitan pizza: processing, distribution, innovation and environmental aspect" (2017SFTX3Y), funded by the Italian Ministry of Instruction, University and Research (MIUR) and by CNR project NUTR-AGE (FOE-2019, DSB.AD004.271). The authors are also grateful to the Smart Agriculture Research and Application Team, Faculty of Applied Sciences, Ton Duc Thang University, Vietnam.

Conflicts of Interest: The authors declare no conflict of interest.

\section{References}

1. Díaz, L.D.; Fernández-Ruiz, V.; Cámara, M. An international regulatory review of food health-related claims in functional food products labeling. J. Funct. Foods 2020, 68, 103896. [CrossRef]

2. Ashaolu, T.J. A review on selection of fermentative microorganisms for functional foods and beverages: The production and future perspectives. Int. J. Food Sci. Technol. 2019, 54, 2511-2519. [CrossRef]

3. Simatende, P.; Gadaga, T.H.; Nkambule, S.J.; Siwela, M. Methods of preparation of Swazi traditional fermented foods. J. Ethn. Foods 2015, 2, 119-125. [CrossRef]

4. De Roos, J.; De Vuyst, L. Acetic acid bacteria in fermented foods and beverages. Curr. Opin. Biotechnol. 2018, 49, 115-119. [CrossRef]

5. Neves, A.; Becker, W.; Dominguez-Torreiro, M. Explained, the Economic Ties between Europe and Asia. World Economic Forum. 2019. Available online: https://www.weforum.org/agenda/2019/05/ways-asia-andeurope-together-connected/\#: \{\}:text=Asia\%2DEurope\%20trade,other\%20regions\%20in\%20the\%20world (accessed on 19 June 2020).

6. Sivamaruthi, B.S.; Kesika, P.; Chaiyasut, C. Thai Fermented Foods as a Versatile Source of Bioactive Microorganisms-A Comprehensive Review. Sci. Pharm. 2018, 86, 37. [CrossRef] [PubMed]

7. Hammes, W.P.; Gänzle, M.G. Sourdough breads and related products. In Microbiology of Fermented Foods; Wood, B.J.B., Ed.; Blackie Academic and Professional: London, UK, 1998; pp. 199-216.

8. Tamang, J.P.; Watanabe, K.; Holzapfel, W.H. Review: Diversity of Microorganisms in Global Fermented Foods and Beverages. Front. Microbiol. 2016, 7, 377. [CrossRef] [PubMed]

9. Steinkraus, K. Fermentations in World Food Processing. Compr. Rev. Food Sci. Food Saf. 2002, 1, $23-32$. [CrossRef]

10. Ashaolu, T.J. Safety and quality of bacterially fermented functional foods and beverages: A mini review. Food Qual. Saf. 2020. [CrossRef]

11. Ray, R.C.; Sivakumar, P.S. Traditional and novel fermented foods and beverages from tropical root and tuber crops. Int. J. Food Sci. Technol. 2009, 44, 1073-1087. [CrossRef]

12. Blandino, A.; Al-Aseeri, M.; Pandiella, S.; Cantero, D.; Webb, C. Cereal-based fermented foods and beverages. Food Res. Int. 2003, 36, 527-543. [CrossRef]

13. Messia, M.C.; Reale, A.; Maiuro, L.; Candigliota, T.; Sorrentino, E.; Marconi, E. Effects of pre-fermented wheat bran on dough and bread characteristics. J. Cereal Sci. 2016, 69, 138-144. [CrossRef]

14. Reale, A.; Mannina, L.; Tremonte, P.; Sobolev, A.P.; Succi, M.; Sorrentino, E.; Coppola, R. Phytate Degradation by Lactic Acid Bacteria and Yeasts during the Wholemeal Dough Fermentation: a31P NMR Study. J. Agric. Food Chem. 2004, 52, 6300-6305. [CrossRef] [PubMed]

15. Reale, A.; Konietzny, U.; D'Auria, S.; Sorrentino, E.; Greiner, R. The Importance of Lactic Acid Bacteria for Phytate Degradation during Cereal Dough Fermentation. J. Agric. Food Chem. 2007, 55, $2993-2997$. [CrossRef] [PubMed]

16. Şanlier, N.; Gökcen, B.B.; Sezgin, A.C. Health benefits of fermented foods. Crit. Rev. Food Sci. Nutr. 2017, 59, 506-527. [CrossRef]

17. Di Renzo, T.; Reale, A.; Boscaino, F.; Messia, M.C. Flavoring Production in Kamut®, Quinoa and Wheat Doughs Fermented by Lactobacillus paracasei, Lactobacillus plantarum, and Lactobacillus brevis: A SPME-GC/MS Study. Front. Microbiol. 2018, 9, 429. [CrossRef]

18. Petrova, P.; Petrov, K. Lactic Acid Fermentation of Cereals and Pseudocereals: Ancient Nutritional Biotechnologies with Modern Applications. Nutrients 2020, 12, 1118. [CrossRef] 
19. Terefe, N.S. Food Fermentation. Ref. Modul. Food Sci. 2016. [CrossRef]

20. Zheng, J.; Wittouck, S.; Salvetti, E.; Franz, C.M.; Harris, H.M.; Mattarelli, P.; O’Toole, P.W.; Pot, B.; Vandamme, P.; Walter, J.; et al. A taxonomic note on the genus Lactobacillus: Description of 23 novel genera, emended description of the genus Lactobacillus Beijerinck 1901, and union of Lactobacillaceae and Leuconostocaceae. Int. J. Syst. Evol. Microbiol. 2020, 70, 2782-2858. [CrossRef]

21. Ashaolu, T.J.; Saibandith, B.; Yupanqui, C.T.; Wichienchot, S. Human colonic microbiota modulation and branched chain fatty acids production affected by soy protein hydrolysate. Int. J. Food Sci. Technol. 2018, 54, 141-148. [CrossRef]

22. Nuraida, L. A review: Health promoting lactic acid bacteria in traditional Indonesian fermented foods. Food Sci. Hum. Wellness 2015, 4, 47-55. [CrossRef]

23. Baschali, A.; Tsakalidou, E.; Kyriacou, A.; Karavasiloglou, N.; Matalas, A. Traditional low-alcoholic and non-alcoholic fermented beverages consumedin European countries: A neglected food group. Nutr. Res. Rev. 2017, 30, 1-24. [CrossRef] [PubMed]

24. Reale, A.; Di Renzo, T.; Succi, M.; Tremonte, P.; Coppola, R.; Sorrentino, E. Microbiological and Fermentative Properties of Baker's Yeast Starter Used in Breadmaking. J. Food Sci. 2013, 78, M1224-M1231. [CrossRef] [PubMed]

25. Reale, A.; Di Renzo, T.; Boscaino, F.; Nazzaro, F.; Fratianni, F.; Aponte, M. Lactic Acid Bacteria Biota and Aroma Profile of Italian Traditional Sourdoughs from the Irpinian Area in Italy. Front. Microbiol. 2019, 10, 1-15. [CrossRef] [PubMed]

26. Gobbetti, M.; Minervini, F.; Pontonio, E.; Di Cagno, R.; De Angelis, M. Drivers for the establishment and composition of the sourdough lactic acid bacteria biota. Int. J. Food Microbiol. 2016, 239, 3-18. [CrossRef] [PubMed]

27. Minervini, F.; Di Cagno, R.; Lattanzi, A.; De Angelis, M.; Antonielli, L.; Cardinali, G.; Cappelle, S.; Gobbetti, M. Lactic acid bacterium and yeast microbiotas of 19 sourdoughs used for traditional/typical italian breads: Interactions between ingredients and microbial species diversity. Appl. Environ. Microbiol. 2011, 78, 1251-1264. [CrossRef]

28. Reale, A.; Di Renzo, T.; Succi, M.; Tremonte, P.; Coppola, R.; Sorrentino, E. Identification of lactobacilli isolated in traditional ripe wheat sourdoughs by using molecular methods. World J. Microbiol. Biotechnol. 2011, 27, 237-244. [CrossRef]

29. Zotta, T.; Piraino, P.; Parente, E.; Salzano, G.; Ricciardi, A. Characterization of lactic acid bacteria isolated from sourdoughs for Cornetto, a traditional bread produced in Basilicata (Southern Italy). World J. Microbiol. Biotechnol. 2008, 24, 1785-1795. [CrossRef]

30. Robert, H.; Gabriel, V.; Fontagné-Faucher, C. Biodiversity of lactic acid bacteria in French wheat sourdough as determined by molecular characterization using species-specific PCR. Int. J. Food Microbiol. 2009, 135, 53-59. [CrossRef]

31. Reale, A.; Tremonte, P.; Succi, M.; Sorrentino, E.; Coppola, R. Exploration of lactic acid bacteria ecosystem of sourdoughs from the Molise region. Ann. Microbiol. 2005, 55, 17-22.

32. De Vuyst, L.; Schrijvers, V.; Paramithiotis, S.; Hoste, B.; Vancanneyt, M.; Swings, J.; Kalantzopoulos, G.; Tsakalidou, E.; Messens, W. The Biodiversity of Lactic Acid Bacteria in Greek Traditional Wheat Sourdoughs Is Reflected in Both Composition and Metabolite Formation. Appl. Environ. Microbiol. 2002, 68, 6059-6069. [CrossRef]

33. Pepe, O. Effect of proteolytic starter cultures as leavening agents of pizza dough. Int. J. Food Microbiol. 2003, 84, 319-326. [CrossRef]

34. Rocha, J.M.; Malcata, F.X. Microbiological profile of maize and rye flours, and sourdough used for the manufacture of traditional Portuguese bread. Food Microbiol. 2012, 31, 72-88. [CrossRef] [PubMed]

35. Rocha, J.M.; Malcata, F.X. On the microbiological profile of traditional portuguese sourdough. J. Food Prot. 1999, 62, 1416-1429. [CrossRef] [PubMed]

36. Rocha, J.M.; Malcata, F.X. Microbial Ecology Dynamics in Portuguese Broa Sourdough. J. Food Qual. 2016, 39, 634-648. [CrossRef]

37. Catzeddu, P. Flour and Breads and Their Fortification in Health and Disease Prevention; Sourdough breads; Academic Press: Cambridge, MA, USA, 2011; pp. 37-46. 
38. Viiard, E.; Bessmeltseva, M.; Simm, J.; Talve, T.; Aaspõllu, A.; Paalme, T.; Sarand, I. Diversity and stability of lactic acid bacteria in rye sourdoughs of four bakeries with different propagation parameters. PLoS ONE 2016, 11, e0148325. [CrossRef]

39. Bartkiene, E.; Lele, V.; Ruzauskas, M.; Domig, K.J.; Starkute, V.; Zavistanaviciute, P.; Bartkevics, V.; Pugajeva, I.; Klupsaite, D.; Juodeikiene, G.; et al. Lactic acid bacteria isolation from spontaneous sourdough and their characterization including antimicrobial and antifungal properties evaluation. Microorganisms 2019, 8, 64 . [CrossRef]

40. Coda, R.; Nionelli, L.; Rizzello, C.G.; De Angelis, M.; Tossut, P.; Gobbetti, M. Spelt and emmer flours: Characterization of the lactic acid bacteria microbiota and selection of mixed starters for bread making. J. Appl. Microbiol. 2010, 108, 925-935. [CrossRef]

41. Moroni, A.V.; Arendt, E.K.; Bello, F.D. Biodiversity of lactic acid bacteria and yeasts in spontaneously-fermented buckwheat and teff sourdoughs. Food Microbiol. 2011, 28, 497-502. [CrossRef]

42. Korcari, D.; Ricci, G.; Quattrini, M.; Fortina, M.G. Microbial consortia involved in fermented spelt sourdoughs: Dynamics and characterization of yeasts and lactic acid bacteria. Lett. Appl. Microbiol. 2019, 70, 48-54. [CrossRef]

43. Harth, H.; Van Kerrebroeck, S.; De Vuyst, L. Impact of process conditions on the microbial community dynamics and metabolite production kinetics of teff sourdough fermentations under bakery and laboratory conditions. Food Sci. Nutr. 2018, 6, 1438-1455. [CrossRef]

44. De Vuyst, L.; Neysens, P. The sourdough microflora: Biodiversity and metabolic interactions. Food Sci. Technol. 2005, 16, 43-56. [CrossRef]

45. Gambuś, H.; Mickowska, B.; Bartoń, H.; Augustyn, G.; Zięć, G.; Litwinek, D.; Szary-Sworst, K.; Berski, W. Health benefits of kvass manufactured from rye wholemeal bread. J. Microbiol. Biotechnol. Food Sci. 2015, 4, 34-39. [CrossRef]

46. Georgala, A. The Nutritional Value of Two Fermented Milk/Cereal Foods Named 'Greek Trahanas' and 'Turkish Tarhana': A review. J. Nutr. Disord. Ther. 2012, S11, 002. [CrossRef]

47. Lazos, E.S.; Aggelousis, G.; Bratakos, M. The fermentation of trahanas: A milk-wheat flour combination. Plant Foods Hum. Nutr. 1993, 44, 45-62. [CrossRef] [PubMed]

48. Osimani, A.; Garofalo, C.; Aquilanti, L.; Milanović, V.; Clementi, F. Unpasteurised commercial boza as a source of microbial diversity. Int. J. Food Microbiol. 2015, 194, 62-70. [CrossRef] [PubMed]

49. Altay, F.; Karbancıoğlu-Güler, F.; Daskaya-Dikmen, C.; Heperkan, D. A review on traditional Turkish fermented non-alcoholic beverages: Microbiota, fermentation process and quality characteristics. Int. J. Food Microbiol. 2013, 167, 44-56. [CrossRef] [PubMed]

50. Gotcheva, V.; Pandiella, S.; Angelov, A.; Roshkova, Z.G.; Webb, C. Microflora identification of the Bulgarian cereal-based fermented beverage boza. Process. Biochem. 2000, 36, 127-130. [CrossRef]

51. Petrova, P.; Petrov, K. Fermented Foods, Part II.; Traditional cereal beverage boza fermentation technology, microbial content and healthy effects; CRC Press: Boca Raton, FL, USA, 2017; pp. 284-305.

52. Botes, A.; Todorov, S.D.; Von Mollendorff, J.W.; Botha, A.; Dicks, L.M.T. Identification of lactic acid bacteria and yeast from boza. Process. Biochem. 2007, 42, 267-270. [CrossRef]

53. Zorba, M.; Hancioglu, O.; Genç, M.; Karapinar, M.; Ova, G. The use of starter cultures in the fermentation of boza, a traditional Turkish beverage. Process. Biochem. 2003, 38, 1405-1411. [CrossRef]

54. Soukand, R.; Pieroni, A.; Biró, M.; Dénes, A.; Dogan, Y.; Hajdari, A.; Kalle, R.; Reade, B.; Mustafa, B.; Nedelcheva, A.; et al. An ethnobotanical perspective on traditional fermented plant foods and beverages in Eastern Europe. J. Ethnopharmacol. 2015, 170, 284-296. [CrossRef]

55. Moora, A. Eesti Talurahva Vanem Toit; Valgus: Tallinn, Estonia, 2007.

56. Grosu-tudor, S.; Stefan, I.; Stancu, M.; Cornea, C.; De vuyst, L.; Zamfir, M. Microbial and nutritional characteristics of fermented wheat bran in traditional Romanian borş production. Romanian Biotechnol. Lett. 2018, 24, 440-447. [CrossRef]

57. Basinskiene, L.; Juodeikiene, G.; Vidmantiene, D.; Tenkanen, M.; Makaravicius, T.; Bartkiene, E. Non-Alcoholic beverages from fermented cereals with increased oligosaccharide content. Food Technol. Biotechnol. 2016, 54, 36-44. [CrossRef]

58. Marsh, A.J.; Hill, C.; Ross, R.P.; Cotter, P. Fermented beverages with health-promoting potential: Past and future perspectives. Trends Food Sci. Technol. 2014, 38, 113-124. [CrossRef] 
59. Dlusskaya, E.; Jänsch, A.; Schwab, C.; Gänzle, M. Microbial and chemical analysis of a kvass fermentation. Eur. Food Res. Technol. 2007, 227, 261-266. [CrossRef]

60. Bautista-Gallego, J.; Arroyo-López, F.N.; Bordons, A.; Jiménez-Díaz, R. Editorial: New Trends in Table Olive Fermentation. Front. Microbiol. 2019, 10, 1880. [CrossRef]

61. Bonatsou, S.; Tassou, S.C.; Panagou, E.Z.; Nychas, G.-J. Table Olive Fermentation Using Starter Cultures with Multifunctional Potential. Microorganisms. 2017, 5, 30. [CrossRef] [PubMed]

62. Heperkan, D. Microbiota of table olive fermentations and criteria of selection for their use as starters. Front. Microbiol. 2013, 4, 143. [CrossRef]

63. Çoşkun, F. A Traditional Turkish Fermented Non-Alcoholic Grape-Based Beverage, "Hardaliye. " Beverages 2017, 3, 2. [CrossRef]

64. Arici, M.; Coskun, F. Hardaliye: Fermented grape juice as a traditional Turkish beverage. Food Microbiol. 2001, 18, 417-421. [CrossRef]

65. Ozcan, M.M.; Uslu, N.; Figueredo, G.; Al Juhaimi, F.; Ghafoor, K.; Babiker, E.E.; Alsawmahi, O.N.; Ozcan, M.M.; Isam, A.; Ahmed, A. The effect of fermentation process on bioactive properties, essential oil composition and phenolic constituents of raw fresh and fermented sea fennel (Crithmum maritimum L.) leaves. Indian J. Trad. Knowl. 2019, 18, 800-804.

66. Maifreni, M.; Marino, M.; Conte, L. Lactic acid fermentation of Brassica rapa: Chemical and microbial evaluation of a typical Italian product (brovada). Eur. Food Res. Technol. 2004, 218, 469-473. [CrossRef]

67. Zabat, M.; Sano, W.; Wurster, J.I.; Cabral, D.J.; Belenky, P. Microbial community analysis of sauerkraut fermentation reveals a stable and rapidly established community. Foods 2018, 7, 77. [CrossRef] [PubMed]

68. Beganović, J.; Kos, B.; Pavunc, A.L.; Uroić, K.; Jokić, M.; Šušković, J. Traditionally produced sauerkraut as source of autochthonous functional starter cultures. Microbiol. Res. 2014, 169, 623-632. [CrossRef] [PubMed]

69. Zielinski, H.; Surma, M.; Zielińska, D. Chapter 21-The naturally fermented sour pickled cucumbers. In Fermented Foods in Health and Disease Prevention; Frias, J., Martinez-Villaluenga, C., Peñas, E., Eds.; Academic Press: Cambridge, MA, USA, 2017; pp. 503-516.

70. Di Cagno, R.; Coda, R.; De Angelis, M.; Gobbetti, M. Exploitation of vegetables and fruits through lactic acid fermentation. Food Microbiol. 2013, 33, 1-10. [CrossRef] [PubMed]

71. Phromraksa, P.; Nagano, H.; Boonmars, T.; Kamboonruang, C. Identification of Proteolytic Bacteria from Thai Traditional Fermented Foods and Their Allergenic Reducing Potentials. J. Food Sci. 2008, 73, M189-M195. [CrossRef]

72. Rhee, S.J.; Lee, J.-E.; Lee, C.-H. Importance of lactic acid bacteria in Asian fermented foods. Microbial Cell Factories 2011, 10, S5. [CrossRef]

73. Pisitkul, C.; Rengpipat, S. Isolation and characterization of lactic acid bacteria starter for preparation of fermented Khanom-jeen. In Proceedings of the 26th Annual Meeting of the Thai Society for Biotechnology and International Conference, Chiang Rai, Thaland, 26-29 November 2014; pp. 353-359.

74. Peng, C.; Borges, S.; Magalhães, R.; Carvalheira, A.; Ferreira, V.; Casquete, R.; Teixeira, P. Characterization of anti-listerial bacteriocin produced by lactic acid bacteria isolated from traditional fermented foods from Cambodia. Int. Food Res. 2017, 24, 386-393.

75. Luangsakul, N.; Keeratipibul, S.; Jindamorakot, S.; Tanasupawat, S. Lactic acid bacteria and yeasts isolated from the starter doughs for Chinese steamed buns in Thailand. LWT Food Sci. Technol. 2009, 42, 1404-1412. [CrossRef]

76. La Anh, N. Health-promoting microbes in traditional Vietnamese fermented foods: A review. Food Sci. Hum. Wellness 2015, 4, 147-161. [CrossRef]

77. Çakır, E.; Arıcı, M.; Durak, M.Z.; Karasu, S. The molecular and technological characterization of lactic acid bacteria in einkorn sourdough: Effect on bread quality. J. Food Meas. Charact. 2020, 14, 1646-1655. [CrossRef]

78. Kivanç, M.; Funda, E.G. A functional food: A traditional Tarhana fermentation. Food Sci. Technol. 2017, 37, 269-274. [CrossRef]

79. Hasanah, U.; Ratihwulan, H.; Nuraida, L. Sensory profiles and lactic acid bacteria density of Tape Ketan and Tape Singkong in Bogor. agriTECH 2019, 38, 265-272. [CrossRef]

80. Yonzan, H.; Tamang, J.P. Microbiology and Nutritional Value ofSelroti, an Ethnic Fermented Cereal Food of the Himalayas. Food Biotechnol. 2010, 24, 227-247. [CrossRef]

81. Yongsmith, B.; Malaphan, W. Traditional Foods; Traditional Fermented Foods in Thailand; Springer: Boston, MA, USA, 2016; pp. 31-59. 
82. Nguyen, D.T.L.; Van Hoorde, K.; Cnockaert, M.; De Brandt, E.; Aerts, M.; Thanh, L.B.; Vandamme, P. A description of the lactic acid bacteria microbiota associated with the production of traditional fermented vegetables in Vietnam. Int. J. Food Microbiol. 2013, 163, 19-27. [CrossRef] [PubMed]

83. Doan, N.T.L.; Van Hoorde, K.; Cnockaert, M.; De Brandt, E.; Aerts, M.; Le Thanh, B.; Vandamme, P. Validation of MALDI-TOF MS for rapid classification and identification of lactic acid bacteria, with a focus on isolates from traditional fermented foods in Northern Vietnam. Lett. Appl. Microbiol. 2012, 55, 265-273. [CrossRef]

84. Kitamura, Y.; Kusumoto, K.I.; Oguma, T.; Nagai, T.; Furukawa, S.; Suzuki, C.; Satomi, M.; Magariyama, Y.; Takamine, K.; Tamaki, H. Ethnic Fermented Foods and Alcoholic Beverages of Asia; Ethnic Fermented Foods and Alcoholic Beverages of Japan; Springer: New Delhi, India, 2016; pp. 193-236.

85. Tamang, J.P.; Sarkar, P.K. Sinki: A traditional lactic acid fermented radish tap root product. J. Gen. Appl. Microbiol. 1993, 39, 395-408. [CrossRef]

86. Franco, W.; Johanningsmeier, S.D.; Lu, J.; Demo, J.; Wilson, E.; Moeller, L. Cucumber Fermentation; Book Chapter; Chapter 7; CRC Press: Boca Raton, FL, USA, 2016; pp. 107-155.

87. Mäki, M. Lactic Acid Bacteria in Vegetable Fermentations. Food Sci. Technol. N. Y. Marcel Dekker 2004, 139, 419-430. [CrossRef]

88. Harris, L.J. Microbiology of Fermented Foods; The microbiology of vegetable fermentations; Springer: Boston, MA, USA, 1998; pp. 45-72.

89. Pino, A.; De Angelis, M.; Todaro, A.; Van Hoorde, K.; Randazzo, C.L.; Caggia, C. Fermentation of Nocellara Etnea Table Olives by Functional Starter Cultures at Different Low Salt Concentrations. Front. Microbiol. 2018, 9, 1125. [CrossRef]

90. Panagou, E.Z.; Tassou, C.C.; Katsaboxakis, C.Z. Induced lactic acid fermentation of untreated green olives of the Conservolea cultivar byLactobacillus pentosus. J. Sci. Food Agric. 2003, 83, 667-674. [CrossRef]

91. Aponte, M.; Ventorino, V.; Blaiotta, G.; Volpe, G.; Farina, V.; Avellone, G.; Lanza, C.M.; Moschetti, G. Study of green Sicilian table olive fermentations through microbiological, chemical and sensory analyses. Food Microbiol. 2010, 27, 162-170. [CrossRef]

92. Garrido-Fernández, A. Effect of processing conditions on lactic acid bacteria growth in table olive fermentation. Actes Colloq. Lact. 1997, 97, 277-316.

93. Arroyo-López, F.N.; Romero-Gil, V.; Bautista-Gallego, J.; Rodriguez-Gomez, F.; Jimenez-Diaz, R.; García-García, P.; Querol, A.; Garrido-Fernandez, A. Yeasts in table olive processing: Desirable or spoilage microorganisms? Int. J. Food Microbiol. 2012, 160, 42-49. [CrossRef] [PubMed]

94. Aponte, M.; Blaiotta, G.; La Croce, F.; Mazzaglia, A.; Farina, V.; Settanni, L.; Moschetti, G. Use of selected autochthonous lactic acid bacteria for Spanish-style table olive fermentation. Food Microbiol. 2012, 30, 8-16. [CrossRef] [PubMed]

95. Papadelli, M.; Zoumpopoulou, G.; Georgalaki, M.; Anastasiou, R.; Manolopoulou, E.; Lytra, I.; Papadimitriou, K.; Tsakalidou, E. Evaluation of Two Lactic Acid Bacteria Starter Cultures for the Fermentation of Natural Black Table Olives (Olea europaea L cv Kalamon). Pol. J. Microbiol. 2015, 64, 265-271. [CrossRef] [PubMed]

96. Benítez-Cabello, A.; Rodríguez-Gómez, F.; Morales, M.L.; Garrido-Fernández, A.; Jiménez-Díaz, R.; Arroyo-López, F.N. Lactic acid bacteria and yeast inocula modulate the volatile profile of spanish-style green table olive fermentations. Foods 2019, 8, 280. [CrossRef] [PubMed]

97. Touret, T.; Oliveira, M.; Semedo-Lemsaddek, T. Putative probiotic lactic acid bacteria isolated from sauerkraut fermentations. PLoS ONE 2018, 13, e0203501. [CrossRef]

98. Di Cagno, R.; Surico, R.F.; Siragusa, S.; De Angelis, M.; Paradiso, A.; Minervini, F.; De Gara, L.; Gobbetti, M. Selection and use of autochthonous mixed starter for lactic acid fermentation of carrots, French beans or marrows. Int. J. Food Microbiol. 2008, 127, 220-228. [CrossRef]

99. Pulido, R.P.; Ben Omar, N.; Abriouel, H.; López, R.L.; Cañamero, M.M.M.; Guyot, J.-P.; Gálvez, A. Characterization of lactobacilli isolated from caper berry fermentations. J. Appl. Microbiol. 2007, 102, 583-590. [CrossRef]

100. Pulido, R.; Benomar, N.; Cañamero, M.; Abriouel, H.; Gálvez, A.; Hui, Y.; Evranuz, E. Handbook of Plant-Based Fermented Food and Beverage Technology, 2nd ed.; Fermentation of Caper Products; CRC Press: Boca Raton, FL, USA, 2012; pp. 201-208.

101. Malinowska-Pańczyk, E. Fermented vegetables products. Food Flavors 2012. [CrossRef] 
102. Tamang, J.P.; Cotter, P.D.; Endo, A.; Han, N.S.; Kort, R.; Liu, S.Q.; Mayo, B.; Westerik, N.; Hutkins, R. Fermented foods in a global age: East meets West. Compr. Rev. Food Sci. Food Saf. 2020, 19, 184-217. [CrossRef]

103. Charalampopoulos, D.; Wang, R.; Pandiella, S.; Webb, C. Application of cereals and cereal components in functional foods: A review. Int. J. Food Microbiol. 2002, 79, 131-141. [CrossRef]

104. Oupathumpanont, O.; Suwonsichon, T. Change of sensory characteristic of fermented rice flour and fermented rice noodle (Kanom-jeen) during fermentation by Lactobacillus plantarum A1. J. Appl. Sci. Res. 2013, 9, 6063-6071.

105. Ly, D.; Mayrhofer, S.; Domig, K. Significance of traditional fermented foods in the lower Mekong subregion: A focus on lactic acid bacteria. Food Biosci. 2018, 26, 113-125. [CrossRef]

106. Keatkrai, J.; Jirapakkul, W. Volatile profile of khanom jeen, Thai fermented rice noodles, and the changes during the fermentation process. Sci. Asia 2010, 36, 46-51. [CrossRef]

107. Bansal, S.; Mangal, M.; Sharma, S.K.; Gupta, R.K. Non-dairy based probiotics: A healthy treat for intestine. Crit. Rev. Food Sci. Nutr. 2015, 56, 1856-1867. [CrossRef]

108. Hamajima, H.; Tanaka, M.; Miyagawa, M.; Sakamoto, M.; Nakamura, T.; Yanagita, T.; Nishimukai, M.; Mitsutake, S.; Nakayama, J.; Nagao, K.; et al. Koji glycosylceramide commonly contained in Japanese traditional fermented foods alters cholesterol metabolism in obese mice. Biosci. Biotechnol. Biochem. 2018, 83, 1514-1522. [CrossRef]

109. Saito, Y.; Wanezaki, K.W.; Kawato, A. Antihypertensive Effects of Peptide in Sake and Its By-products on Spontaneously Hypertensive Rats. Biosci. Biotechnol. Biochem. 1994, 58, 812-816. [CrossRef]

110. Jeon, H.J.; Noda, M.; Maruyama, M.; Matoba, Y.; Kumagai, T.; Sugiyama, M. Identification and Kinetic Study of Tyrosinase Inhibitors Found in Sake Lees. J. Agric. Food Chem. 2006, 54, 9827-9833. [CrossRef]

111. Yamamoto, S.; Nakashima, Y.; Yoshikawa, J.; Wada, N.; Matsugo, S. Radical scavenging activity of the japanese traditional food, Amazake. Food Sci. Technol. Res. 2011, 17, 209-218. [CrossRef]

112. Maruki-Uchida, H.; Sai, M.; Yano, S.; Morita, M.; Maeda, K. Amazake made from sake cake and rice koji suppresses sebum content in differentiated hamster sebocytes and improves skin properties in humans. Biosci. Biotechnol. Biochem. 2020, 1-7. [CrossRef]

113. Oguro, Y.; Nishiwaki, T.; Shinada, R.; Kobayashi, K.; Kurahashi, A. Metabolite profile of koji amazake and its lactic acid fermentation product by Lactobacillus sakei UONUMA. J. Biosci. Bioeng. 2017, 124, 178-183. [CrossRef] [PubMed]

114. Ertaş, N.; Sert, D.; Demir, M.K.; Elgün, A. Effect of whey concentrate addition on the chemical, nutritional and sensory properties of tarhana (a Turkish Fermented Cereal-based Food). Food Sci. Technol. Res. 2009, 15, 51-58. [CrossRef]

115. Özel, S.; Sabanoğlu, S.; Çon, A.H.; Simsek, O. Diversity and stability of yeast species during the fermentation of tarhana. Food Biotechnol. 2015, 29, 117-129. [CrossRef]

116. Bayrakçı, H.A.; Bilgiçli, N. Influence of resistant starches on chemical and functional properties of tarhana. J. Food Sci. Technol. 2014, 52, 5335-5340. [CrossRef]

117. Arici, M.; Dağlıoğlu, O. Boza: A lactic acid fermented cereal beverage as a traditional Turkish food. Food Rev. Int. 2002, 18, 39-48. [CrossRef]

118. Akpinar-Bayizit, A.; Yilmaz-Ersan, L.; Ozcan, T. Determination of boza's organic acid composition as it is affected by raw material and fermentation. Int. J. Food Prop. 2010, 13, 648-656. [CrossRef]

119. Sujaya, I.N.; Nocianitri, K.A.; Asano, K. Diversity of bacterial flora of Indonesian ragi tape and their dynamics during the tape fermentation as determined by PCR-DGGE. Int. Food Res. J. 2010, 17, 239-245.

120. Ganzle, M.G.; Salovaara, H. Lactic acid bacteria in cereal-based products. In Lactic Acid Bacteria: Microbiological and Functional Aspects; Vinderola, G., Ouwehand, A., Salminen, S., von Wriu, A., Eds.; CRC Press: Boca Raton, FL, USA, 2019; pp. 199-208.

121. Ai-Lati, A.; Liu, S.; Li, X.; Qian, B.; Shan, Y.; Zhou, Z.; Peng, L.; Ji, Z.; Mao, J.; Zou, H.; et al. Effect of Chinese rice wine sludge on the production of Chinese steamed buns. J. Food Process. Preserv. 2018, 42, e13572. [CrossRef]

122. Puspito, H.; Fleet, G. Microbiology of sayur asin fermentation. Appl. Microbiol. Biotechnol. 1985, 22, $442-445$. [CrossRef]

123. Tanasupawat, S.; Komagata, K. Lactic acid bacteria in fermented foods in Thailand. World J. Microbiol. Biotechnol. 1995, 11, 253-256. [CrossRef] 
124. Viander, B.; Mäki, M.; Palva, A. Impact of low salt concentration, salt quality on natural large-scale sauerkraut fermentation. Food Microbiol. 2003, 20, 391-395. [CrossRef]

125. Chen, Y.-S.; Yanagida, F.; Hsu, J.-S. Isolation and characterization of lactic acid bacteria from suan-tsai (fermented mustard), a traditional fermented food in Taiwan. J. Appl. Microbiol. 2006, 101, 125-130. [CrossRef] [PubMed]

126. Yan, P.M.; Xue, W.T.; Tan, S.S.; Zhang, H.; Chang, X.H. Effect of inoculating lactic acid bacteria starter cultures on the nitrite concentration of fermenting Chinese paocai. Food Control. 2008, 19, 50-55. [CrossRef]

127. Chang, C.H.; Chen, Y.S.; Yanagida, F. Isolation and characterization of lactic acid bacteria from yan-jiang (fermented ginger), a traditional fermented food in Taiwan. J. Sci. Food Agric. 2011, 91, 1746-1750. [CrossRef] [PubMed]

128. Chen, Y.S.; Wu, H.C.; Lo, H.Y.; Lin, W.C.; Hsu, W.H.; Lin, C.W.; Lin, P.Y.; Yanagida, F. Isolation and characterization of lactic acid bacteria from jiang-gua (fermented cucumbers), a traditional fermented food in Taiwan. J. Sci. Food Agric. 2012, 92, 2069-2075. [CrossRef] [PubMed]

129. Chen, Y.S.; Wu, H.C.; Wang, C.M.; Lin, C.C.; Chen, Y.T.; Jhong, Y.J.; Yanagida, F. Isolation and characterization of lactic acid bacteria from pobuzihi (fermented cummingcordia), a traditional fermented food in Taiwan. Folia Microbiol. 2013, 58, 103-109. [CrossRef]

130. Swain, M.R.; Anandharaj, M.; Ray, R.C.; Rani, R.P. Fermented fruits and vegetables of asia: A potential source of probiotics. Biotechnol. Res. Int. 2014, 2014, 1-19. [CrossRef]

131. Tamang, J.; Thapa, N.; Tamang, B.; Rai, A.; Chettri, R. Health Benefits of Fermented Foods and Beverages; Microorganisms in fermented foods and beverages; CRC Press: Boca Raton, FL, USA, 2015; pp. 1-110.

132. Medina, E.; De Castro, A.; Romero, C.; Ramírez, E.M.; Brenes, M. Safety of fermented fruits and vegetables. Regul. Saf. Tradit. Ethn. Foods 2016, 355-367. [CrossRef]

133. Shin, G.H.; Kang, B.C.; Jang, D.J. Metabolic Pathways Associated with Kimchi, a Traditional Korean Food, Based onIn SilicoModeling of Published Data. Genom. Inform. 2016, 14, 222-229. [CrossRef]

134. Park, K.Y.; Kim, H.Y.; Jeong, J.K. Chapter 20-Kimchi and its health Benefits A2-Frias, Juana. In Fermented Foods in Health and Disease Prevention; Martinez-Villaluenga, C., Peñas, E., Eds.; Academic Press: Boston, MA, USA, 2017; pp. 477-502.

135. Meidong, R.; Doolgindachbaporn, S.; Jamjan, W.; Sakai, K.; Tashiro, Y.; Okugawa, Y.; Tongpim, S. A novel probiotic Bacillus siamensis B44v isolated from Thai pickled vegetables (Phak-dong) for potential use as a feed supplement in aquaculture. J. Gen. Appl. Microbiol. 2017, 63, 246-253. [CrossRef]

136. De Filippis, F.; Parente, E.; Ercolini, D. Metagenomics insights into food fermentations. Microb. Biotechnol. 2017, 10, 91-102. [CrossRef] [PubMed]

137. Garofalo, C.; Ferrocino, I.; Reale, A.; Sabbatini, R.; Milanović, V.; Alkić-Subašićd, M.; Boscaino, F.; Aquilanti, L.; Pasquini, M.; Trombetta, M.F.; et al. Study of kefir drinks produced by backslopping method using kefir grains from Bosnia and Herzegovina: Microbial dynamics and volatilome profile. Food Res. Int. 2020, 137, 109369. [CrossRef]

138. Marui, J.; Boulom, S.; Panthavee, W.; Momma, M.; Kusumoto, K.-I.; Nakahara, K.; Saito, M. Culture-independent bacterial community analysis of the salty-fermented fish paste products of Thailand and Laos. Biosci. Microbiota Food Health 2015, 34, 45-52. [CrossRef] [PubMed]

139. Nguyen, D.T.L.; Van Hoorde, K.; Cnockaert, M.; De Brandt, E.; De Bruyne, K.; Le, B.T.; Vandamme, P. A culture-dependent and -independent approach for the identification of lactic acid bacteria associated with the production of nem chua, a Vietnamese fermented meat product. Food Res. Int. 2013, 50, 232-240. [CrossRef]

140. Wanangkarn, A.; Liu, D.; Swetwiwathana, A.; Jindaprasert, A.; Phraephaisarn, C.; Chumnqoen, W.; Tan, F.J. Lactic acid bacterial population dynamics during fermentation and storage of Thai fermented sausage according to restriction fragment length polymorphism analysis. Int. J. Food Microbiol. 2014, 186, 61-67. [CrossRef]

141. Moe, N.K.T.; Thwe, S.M.; Shirai, T.; Terahara, T.; Imada, C.; Kobayashi, T. Characterization of lactic acid bacteria distributed in small fish fermented with boiled rice in Myanmar. Fish. Sci. 2015, 81, 373-381. [CrossRef] 
142. Woraprayote, W.; Pumpuang, L.; Tosukhowong, A.; Roytrakul, S.; Perez, R.; Zendo, T.; Sonomoto, K.; Benjakul, S.; Visessanguan, W. Two putatively novel bacteriocins active against Gram-negative food borne pathogens produced by Weissella hellenica BCC 7293. Food Control. 2015, 55, 176-184. [CrossRef]

143. Jagadeesan, B.; Gerner-Smidt, P.; Allard, M.W.; Leuillet, S.; Winkler, A.; Xiao, Y.; Chaffron, S.; Van Der Vossen, J.; Tang, S.; Katase, M.; et al. The use of next generation sequencing for improving food safety: Translation into practice. Food Microbiol. 2019, 79, 96-115. [CrossRef]

(c) ( 